\title{
STUDY OF INTERACTIVE LEARNING SPREADS WITHIN EDUCATIONAL ESTABLISHMENTS
}

\section{Hoda Gad El Rab Abdo MDKOUR*}

Department of Interior Design, College of Art and Design, University of Modern Sciences and Arts, Egypt

\begin{abstract}
Learning takes place in spaces that are not limited to the classroom, as it is a process that occurs everywhere within the educational facility, from the classroom to the corridors, roads, etc. Learning spaces within educational facilities are classified into formal and informal learning spaces. The official learning space is the space that is used according to regular official appointments, and these spaces vary to include classes, lecture halls, laboratories, ceremonies ... etc. There are several factors that affect the design of formal learning spaces, including: The development in pedagogy: The pedagogy has witnessed a shift towards active learning and cooperative learning, as well as a variety of teaching methods According to the need of the academic subject, which results in arranging the semester according to the method of teaching followed. New students' qualities and habits: Understanding students 'characteristics and habits helps in designing and developing learning spaces. There are five important features for new students that must be taken care of and taken into account: digital, mobile, independence, social, and participatory. Rapid development in educational communication technology: It means all digital technological devices, means, software and media and non-digital technologies that are integrated into the learning process, and education technologies can be divided into three categories: virtual technologies, installed devices, And mobile devices. The trend towards the human being at the center of design: through concern for some features, among which are health (and includes: physical comfort Good lighting - acoustics - indoor air quality), stimulation (through attention to sensory cues - contact with nature, shapes various color), adaptation (through flexibility - sufficient space - portable display - communication of various information. Informal learning space is a space inside the educational facility that allows students to practice and discuss academic work without committing to deadlines Official. The spaces that represent informal learning spaces are varied and include outdoor space, corridors, lobbies and lounges, coffee shop, and library. There are factors that affect the success of informal learning spaces, including: Spaces are compatible with the needs of learners. Striking a balance between society and isolation. Stimulus. Availability of technology and ease of contact with information. Adaptation.

Keywords

Interactive, Learning, Spreads, Educational, Establishments.
\end{abstract}

\section{Introduction}

A change in design thinking has emerged as a result of an awareness of the environmental impacts associated with modern construction and their impact on humans and the environment. Hence, some new concepts and methods that were not previously familiar in designing and implementing projects, including "sustainable design" and "green architecture" all reflect interest. The growing urban sectors have issues of economic development in light of protecting the environment, reducing energy consumption, optimal utilization of natural resources, and relying more on renewable energy sources. It can be dispensed with or lived without, so this technology has been targeted in ways that achieve adaptation to And to provide a suitable internal environment, which was known as smart architecture. And because the primary goal of design is human beings, the concept of interactivity arose as a guide to action resulting from

*Corresponding author: info@msa.eun.eg 
the study of behavior And which concerned with the human experience as a source of knowledge, this approach has addressed the social pragmatic of pragmatic philosophy.

1. Social problems such as boredom for leisure, rest and preference for one place over another, as well as psychological and mental illnesses that modern life has generated, hoping to uncover these problems and work to develop appropriate solutions for them. Hence the role of interactive architecture in drawing general lines to see the future in a better way through understanding the situation, studying it and integrating it with technology in order to meet the changing needs of the individual, society and the environment.

\section{Research Problem:}

The research problem arises in:

1. The need to design internal holdings that adapt to environmental variables and meet changing human needs

2. The need to design interactive learning holdings that are more flexible and more adaptive to the requirements and needs of the individual and society

3. The educational process. These holdings are not limited to formal learning holdings only, but rather extend to include informal holdings.

\section{Research Importance:}

The importance of the research is due to:

1. Study the concept of interactivity and its origins and reach the limitations of the interactive space.

\section{Research Aims:}

The research aims to reach:

The concept of interactive space and its limitations.

Changes and circumstances that led to a review of the design of educational facilities.

Study the new concept of learning holdings.

\section{Research Hypotheses:}

The research is based on the following hypotheses:

The existence of an interactive relationship between the human being and the internal space There is a strong link between digital technology and people.

\section{Research Methodology:}

The research uses the descriptive and analytical method in extracting the factors forming the interactive holdings

The concept of interactive space

- The interactive space is an environment that interacts with the people in it, as these 
environments touch the activity of people and interact through various presentations: audio, visual, kinesthetic and tactile.

2. Upgrading the internal holdings to achieve the greatest efficiency and flexibility for users of the space 1- The interactive space is a space that has the ability to meet the changing individual, social and environmental needs, and it is a space characterized by intelligence, flexibility and adaptation according to the changes on it. (Interactive) informal learning holdings

An informal learning space is a space within an educational facility that allows students to conduct and discuss academic work without commitment.

On official dates, and the spread of these holdings varies according to the type of educational facility, schools are limited, for example, to outdoor holdings (open air space).

They practice basic learning processes while sitting and walking, such as observation, examination, reflection, data collection and recording, group participation and discussions.

3- In addition to preserving children's health as they are exposed to natural air that helps them focus. Colleges and universities have a variety of informal learning holdings where students spend long periods of their time outside of formal learning holdings (classrooms), so it is important for students to spend This time discussing academic work with colleagues, so these holdings vary to include holdings. Internal and external.

\section{References}

1- Najwan Shehata - nanotechnology and its impact on the development of interactive interior design - published research - the third conference of visual arts between - variable and fixed 2117

2- Saeed Ahmed Hassan: University Library, Dar Jabal - Beirut - First Edition 1992.

3- Rudd, Tim, Reimagining Outdoor Learning Spaces ( primary capital, Co- design and education transformation), futurelab handbook, 2008, publications.becta.org.uk.

4- Gamals, Ahmed, Engaging \& retaining students using cutting - edge Technologies ( Design of the Outdoor, classroom \& Electronic Learning Spaces), International HETL conference, Orlando, Florida, January 13-5-2013

5- Oblinger, Diana G, Learning spaces, e-book, educase , 2006, www.educase.edu/learning space.04-01-2015.

6- www.steelcase.com/en/.../ses_active_learning_spaces_interactive.final.pd pp.39.04-012015.

7- Judith H. Heerwagen, “Design, Productivity, and Well-Being: What Are the Links?” paper presented at the American Institute of Architects Conference on Highly Effective Facilities, March 1998, Cincinnati. 
8- Hala Marouf AMER, MODERN METHODS OF PIANO PERFORMANCE IN KLOSTER DRIAN'S COMPOSITIONS, International Journal of Education and Learning Research, Vol. 1, No. 2, 2018, pp. 1-3.

9- Muhammad Ali Mahmoud NASRA, MODIFY THE JOHANNES ITTEN CIRCLE OF COLORS TO CREATE HARMONIOUS COLOR GROUPS TO DEVELOP THE TEACHING OF COLOR SCIENCE, International Journal of Education and Learning Research, Vol. 1, No. 2, 2018, pp. 4-13.

Received: February 6, 2019

Accepted: April 15, 2019 